\title{
Prehispanic foods oyster mushroom (Pleurotus ostreatus), no- pal (Opuntia ficus-indica) and amaranth (Amaranthus sp.) as new alternative ingredients for developing functional cookies
}

\author{
Georgina Uriarte-Frías ${ }^{1}$, Martha M. Hernández-Ortega ${ }^{1}$, Gabriela Gutiérrez-Salmeán ${ }^{1}$, \\ Miriam Magale Santiago-Ortiz ${ }^{1}$, Humberto J. Morris-Quevedo ${ }^{2, *}$ and Marcos Meneses-Mayo ${ }^{1, *}$ \\ 1 Centro de Investigación en Ciencias de la Salud (CICSA), Facultad de Ciencias de la Salud, Universidad \\ Anáhuac México, Lomas Anáhuac, Huixquilucan, Estado de México 52786, México; \\ gina_uriarte@hotmail.com (G.U.F.); gabriela.gutierrez@anahuac.mx (G.G.S.); \\ martha.hernandezor@anahuac.mx (M.M.H.O.); miriamsantiagoo@anahuac.mx (M.M.S.O.) \\ 2 Centro de Estudios de Biotecnología Industrial (CEBI), Universidad de Oriente, Ave, Patricio Lumumba s/n \\ Reparto Jiménez, Santiago de Cuba 90500, Cuba \\ * Correspondence: marcos.meneses@anahuac.mx (M.M.M.); jquevedo@uo.edu.cu (H.J.M.Q.) \\ Tel.: (55) 56.27.02.10 ext. 7247 (M.M.M.); (53) 22.63.20.95 (H.J.M.Q.)
}

\begin{abstract}
Oyster mushroom (Pleurotus ostreatus), nopal (Opuntia ficus-indica) and amaranth (Amaranthus spp.) are pre-hispanic foods widely consumed in Mexico. However, there are no standard products developed with these ingredients as functional cookies. This study evaluated the impact of partial replacement (50\%) of whole-wheat flour (WWF) with three formulations of $P$. ostreatus, nopal and amaranth flours (POF, NF and AF, respectively) in the nutritional/antioxidant properties of fortified cookies. The proportion of flours' ingredients (WWF:AF:NF:POF) were $100 \%$ WWF (traditional cookies), 50:35:10:5 (formulation 1), 50:30:15:5 (formulation 2) and 50:40:5:5 (formulation 3). Proximal composition, phenolic/flavonoid contents, and ABTS*+ scavenging activity were determined in flours and cookies. POF, NF and AF possess a high nutritional value comprising polyphenols/flavonoids and a significant antioxidant potential. Total protein, ashes and flavonoids were higher in fortified cookies than controls. Cookies prepared with Formulation 2 -highest nopal level- contained 5.29\% of dietary fiber and 5-times higher polyphenol content than control cookies. The ABTS ${ }^{*+}$ scavenging ability was similar in the three enriched cookies (87.73$89.58 \%$ ) but higher than traditional cookies $(75.60 \%)$. Applicability of POF/NF/AF for replacing up to $50 \%$ of WWF in production of functional cookies was demonstrated. The research promotes renewable local bioresouces for a sustainable agri-food chain, especially edible mushrooms.
\end{abstract}

Keywords: amaranth; antioxidant; cookies; functional foods; mushrooms; nopal; nutraceuticals; Pleurotus ostreatus; polyphenols; prehispanic foods

\section{Introduction}

Non-communicable diseases (NCDs) are the main health and development challenge facing humankind all over the world in the twenty-first century. NCDs -namely cardiovascular diseases, diabetes, cancer and chronic respiratory diseases- have a higher morbidity and mortality rate globally than do all causes combined. By 2030, the global average age-standardized NCDs mortality rate would be 510.54 (per 100,000 population) and the global average mortality for NCDs deaths of the total number of deaths would be $75.26 \%$ [1]. On the other hand, malnutrition is one of the main public health problems affecting many countries and is associated, in many cases, with the high intake of hypercaloric foods with low dietary fiber, minerals and vitamins [2].

Functional foods and nutraceuticals $(\mathrm{FF} / \mathrm{Ns})$ have received considerable interest in the past decade, largely due to increasing consumer awareness of the health benefits associated with food and nutrition [3]. In the current pandemic of NCDs and malnutrition, 
as well as in the nutritional transition, particularly in Latin America, the use of native $\mathrm{FF} / \mathrm{Ns}$ represents an attractive target for the treatment and/or prevention of these conditions. FF/Ns have been consumed since pre-Hispanic times as a part of the regular diet and some of them have transcended, and are consumed in different countries around the globe. Examples of iconic pre-Hispanic FF/Ns in the Mexican and Central American diet include amaranth, nopal and mushrooms (mainly the oyster mushroom Pleurotus ostreatus), among others [4]. Hence, the interest to make culturally rooted foods with greater nutritional value and medical benefits in order to contribute to a healthier diet of the population.

Edible and medicinal mushrooms are now the emerging and most important microbial agri-food chain in Mexico, showing a good impact on food production for human consumption and as endless source of novel compounds with medicinal properties, which are different from those found in foods of plant and animal origin [5].

Pleurotus spp. is the second most important mushroom of culinary value worldwide. Pleurotus species have been recognized as a high nutritional value-food containing bioactive molecules with therapeutic effects [6]. Particularly, Pleurotus ostreatus is highlighted by its therapeutic properties such as anti-inflammatory, antimicrobial, antiviral, antitumor, antioxidant, antimutagenic, cardioprotective, antidiabetic, and immunomodulatory, among others $[7,8]$. These effects are attributed to the presence of biologically active compounds such as polysaccharides, peptides, proteins, glycoproteins, polyphenols, nucleotides, triterpenoids, lectins, lipids, and other complex compounds [9]. Particularly, the antioxidant properties of $P$. ostreatus have been well documented in both mycelium and fruiting bodies at different maturation stages [10,11].

Pleurotus mushrooms have become a staple food because of the variety in processing and consumption. In previous studies, some Pleurotus species were investigated as food additives: (i) the addition of $P$. sajor-caju to selected wheat- and rice-based products [12]; (ii) the incorporation of oyster mushroom into biscuits in the range of 5-30\% [13]; (iii) the production of Fettuccine pasta with partial replacement of wheat flour with $P$. ostreatus flour at $10 \%$ and $20 \%$ [14]; and (iv) sponge cakes supplemented with dried P. sajor-caju powder at $5 \%, 7 \%, 10 \%$ and $12 \%$ [15]. However, the use of Pleurotus spp. in the formulation of industrialized food is not fully exploited.

An innovative and unexplored approach consists on combining Pleurotus mushrooms (e.g. dehydrated powder) with other traditionally consumed foods such as nopal (Opuntia ficus-indica (L.) Mill) and amaranth (Amaranthus sp.) taking advantage of their high nutritional value and biological activities.

Nopal is by far the most important cactus worldwide, and domestication of this plant was one of the most important inheritances left by ancient people in Mexico, which is the largest producer [16]. During last decades, several scientific studies were conducted on Opuntia ficus-indica promoting its nutritional value, due to a rich composition in amino acids, polyunsaturated fatty acids, vitamins and dietary fiber contents $[17,18]$. Additionally, there are ample evidences of the health benefits of nopal consumption including anticancer properties or cancer chemoprevention issues, and antidiabetic, cardioprotective, anti-inflammatory, antibacterial and antiulcer activities, among others [19]. Recent trends in nutraceuticals' research aroused scientists' interest to study the effects of nopal bioactive compounds -mainly polyphenols- to scavenge free radicals in oxidative stress related diseases [20,21].

On the other hand, amaranth is one of the oldest known edible vegetables found in Tehuacan, Puebla, Mexico, about 4000 BC ago in earliest archeological record and was a major food crop of the Aztecs. This pseudocereal is considered as a "superfood" because it possesses a high nutritional value, such as a high-quality protein, unsaturated oils, dietary fiber, tocopherols, phenolic compounds, flavonoids, vitamins, and minerals [22]. Many health effects have been attributed to this plant comprising hypocholesterolemic 
activity, influence on the immune system, antitumor effect, action on blood glucose levels, effects on liver functions, celiac disease, and antiallergic action [23]. In view of its phytochemicals, amaranth can be considered as an antioxidant rich food [24].

An attempt was made to elaborate formulations for nutritional bars based on the aforementioned foods, and the effect of those formulations were evaluated on a murine model of diet-induced cardio metabolic disruption [25]. However, in the area of food technology an important market for cookies as very popular snacks has emerged because of, they are ready-to-eat, quite durable products with long shelf life [26]. Moreover, they represent a matrix suitable for fortification, thus providing an opportunity for the intake of important nutrients [27]. To the best of our knowledge, there are no standard products developed with Pleurotus mushroom, nopal and amaranth in the form of combined functional cookies. These foods have in common a high nutritional value with a good myco-/phytochemical profile and natural antioxidants harboring a great antioxidant potential.

In this context, the purpose of this research was to evaluate the impact of partial replacement $(50 \%)$ of wheat flour with three formulations of oyster mushroom, nopal and amaranth flours in the elaboration of functional cookies. The hypothesis proposed was that the partial replacement of wheat flour with the mentioned flours from traditional Mexican foods improves its nutritional contribution in total protein, dietary fiber and mineral contents, as well as, in the antioxidant capacity of cookies enriched with these natural ingredients. This study intends to contribute to fortifying traditional types of cookies that lack nutraceutical compounds and antioxidant activity, by replacing a significant portion of wheat flour with iconic culturally foods, thus providing reliable insight into fortified cookies functionality. The research also promotes the renewable local bioresouces for a sustainable agri-food chain in the framework of Sustainable Development Goals (SDGs).

\section{Materials and Methods}

\subsection{Chemicals and Samples}

Gallic acid, Folin-Ciocalteu's reagent, hydrochloric acid, sodium acetate trihydrate, glacial acetic acid, sulfuric acid, aluminum chloride, sodium nitrate, sodium carbonate (anhydrous), acetone, ethanol and sodium hydroxide were purchased from Merck (México, S.A, de C.V., Naucalpan, México).

The 2,2-azino-bis-(3-ethylbenzothiazoline-6-sulfonic acid) (ABTS*), epicatechin, potassium persulfate, ethyl ether were purchased from Sigma-Aldrich Chemical Co. (St. Louis, MO, USA). Redistilled water was used for the preparation of solutions. All chemicals were of analytical grade.

All the baking ingredients in customary quality, such as high grade Whole Wheat Flour (WWF), margarine, white sugar, eggs, vanilla extract and salt were purchased from the local market. All samples in the original packaging were stored at ambient temperature until further processing.

\subsection{Mushroom and Plant Material for Biofunctional Flours Preparation}

Mushroom and plant material used in this work for biofunctional flours preparation are shown in Figure 1. Fresh Pleurotus ostreatus (Jacq:Fr.) Kumm (Pleurotaceae) was provided by "Hongos El Dorado GPO" (Ixtlahuaca, Estado de México, México). Mushroom was sliced in small pieces and dehydrated for $6 \mathrm{~h}$ at $57^{\circ} \mathrm{C}$ using a NESCO ${ }^{\circledR}$ Gardenmaster food dehydrator model FD-1010PC, series 10B1109D1 (Nesco ${ }^{\circledR}$ American, Two Rivers, WI, USA). Afterward, the dried material was homogenized during 3 min with 
a FOSS 2094 homogenizer and then milled with a food grinder Foss Tecator 1093 Cyclotec Sample Mill (FOSS Centro America, S.A de C.V., Mexico).

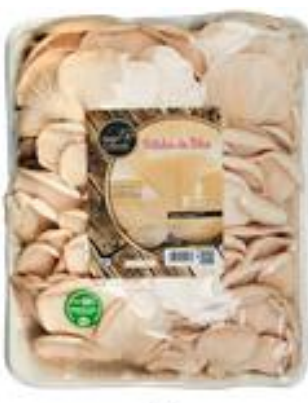

(a)

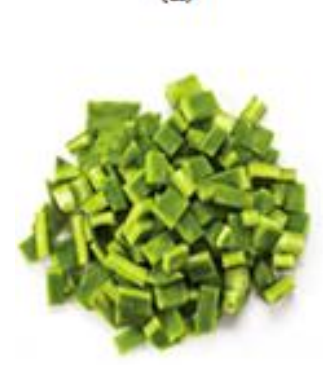

(d)

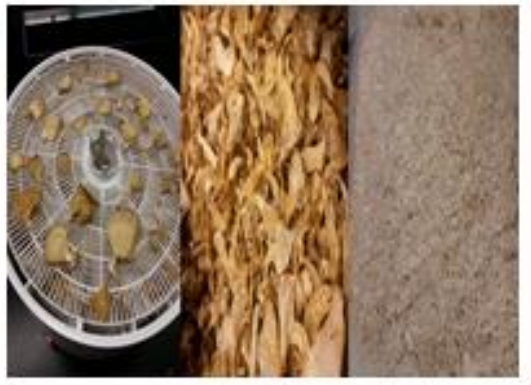

(b)

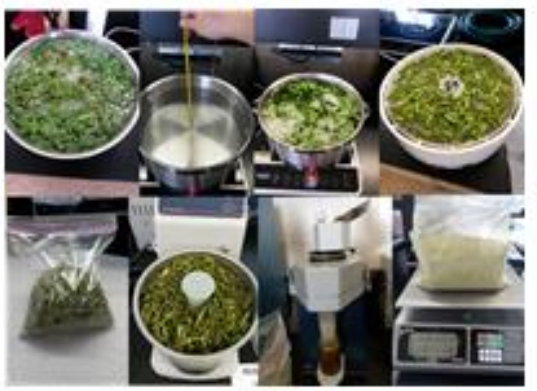

(e)

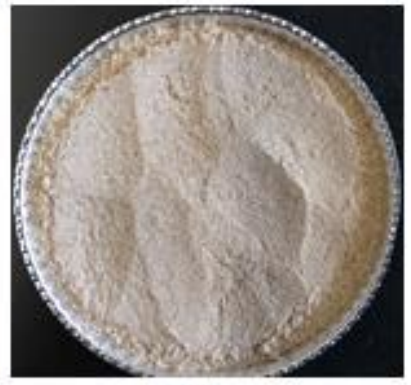

(c)

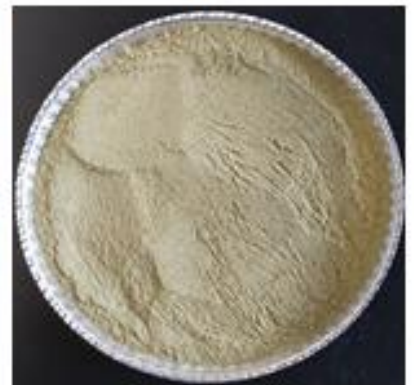

(f)

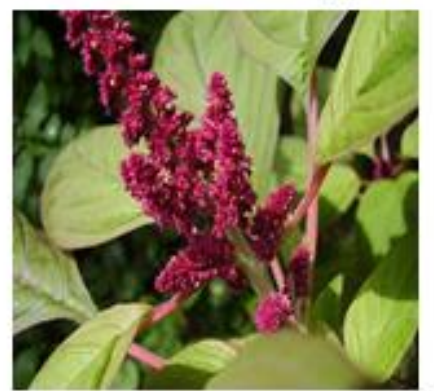

(g)

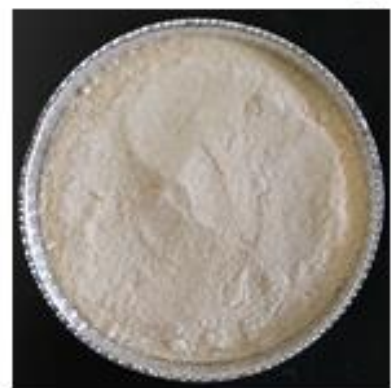

(h)

Figure 1. Mushroom and plant material for biofunctional flours preparation. (a) Commercial cultivated Pleurotus ostreatus (oyster mushroom) (Hongos El Dorado, México); (b) Process for obtaining Pleurotus ostreatus' flour by slicing-dehydrating-grinding steps; (c) Pleurotus ostreatus' flour; (d) Commercial nopal (Opuntia ficus-indica L.) fragments (COLPOS, Texcoco, México); (e) Process for obtaining nopal's flour by slicing-dehydrating-grinding steps; (f) Nopal's flour; (g) Amaranth's plant; (h) Commercial amaranth's flour (Amapharma Division, Grupo NUTRISOL S.A., México).

Nopal (Opuntia ficus-indica L.) Mill was obtained from the experimental station of the Colegio de Posgraduados (Montecillo, Texcoco, Estado de México). Fresh nopal pads was disinfected with Microdyn ${ }^{\circledR}$ (Tavistock Holding AG., produced by Mercancías Salubres, S.A. de C.V., Ciudad de México) for $10 \mathrm{~min}$ in order to eliminate microorganisms, cut into small sections, and then scalding at $70{ }^{\circ} \mathrm{C}$ for one minute. After that, it was dehydrated for $10 \mathrm{~h}$ at $57{ }^{\circ} \mathrm{C}$, homogenized and milled with the equipment aforementioned. Both Pleurotus ostreatus and nopal flours (POF and NF, respectively) were packed at vacuum (Besser Vacum Profesional Kitchen equipment FRESH 43, Italy) in airtight closed polyethylene bags and kept in common storage conditions before analysis and application in confectionery.

Amaranth seed flour (AF) was produced in the Plant San Miguel de Proyectos Agropecuarios, S.P.R. de R.S. (Huichapan, Hidalgo, México) and purchased from Grupo 
Nutrisol S.A. de C.V. (División Amapharma, México, D.F.). All bags containing biofunctional flours were covered with aluminium foil and stored protected from the light.

\subsection{Formulation and Production of Fortified Cookies with Biofunctional Flours}

Standard cookie dough (control) was elaborated according to a traditional method. Whole wheat flour cookies (control) and biofunctional flour-enriched cookies were prepared based on the different formulations presented in Table 1. The amount of POF to be incorporated in fortified cookies was established at the level of $5 \%$ based on a previous work [28] and health benefits observed at this level in an in vivo intervention study [25]. Fortified cookies were produced by replacing $50 \%$ of wheat flour with the indicated proportions of biofunctional flours. For all formulations, shortening was creamed, blended with sugar and egg in a mixer and then wheat flour and biofunctional flours were sieved into the above dough and mixed again until homogenous appearance was reached. The dough was rolled and cut into different shapes identifying formulations and baked at $180{ }^{\circ} \mathrm{C}$ for $12 \mathrm{~min}$ in a convection oven (San-Son Combi SHC-10®, Naucalpan, Edo. México). After then, cookies were cooled at room temperature for $30 \mathrm{~min}$ and stored in hermetic containers, at ambient temperature and protected from the light until analysis. The microscopical appearance of cookies was observed at 40x magnification under an Olympus SZ4045 Stereo Microscope series 580067 (Olympus Corp., Tokyo, Japan).

Table 1. Composition of control (While Wheat Flour -WWF-based formulation) and those fortified with the three alternative flours obtained from functional ingredients used in cookies' preparation (g/100 $\mathrm{g}$ of formulation).

\begin{tabular}{lcccc}
\hline \multirow{1}{*}{ Ingredients } & \multicolumn{4}{c}{ Formulations } \\
\cline { 2 - 5 } & Control & F 1 & F 2 & F 3 \\
\hline Flours & & & & 17.4 \\
\hline Whole wheat flour (WWF) & 34.9 & 17.4 & 1.7 & 1.7 \\
Pleurotus ostreatus flour & - & 1.7 & & \\
(POF) & & & 5.2 & 1.7 \\
Nopal flour (NF) & - & 3.5 & 10.5 & 13.9 \\
Amaranth flour (AF) & - & 12.2 & $\mathbf{5 0 : 3 0 : 1 5 : 5}$ & $\mathbf{5 0 : 4 0 : 5 : 5}$ \\
Proportion of flours' & $\mathbf{1 0 0 \%}$ & $\mathbf{5 0 : 3 5 : 1 0 : 5}$ & & \\
ingredients & $\mathbf{W W F}$ & & & \\
(WWF:AF:NF:POF) & & & 41.5 & 41.5 \\
\hline Other ingredients & & & 19.9 & 19.9 \\
\hline Margarine without salt & 41.5 & 41.5 & 2.5 & 2.5 \\
Sugar & 19.9 & 19.9 & 1.1 & 1.1 \\
Egg yolk & 2.5 & 2.5 & 0.1 & 0.1 \\
Vanilla extract & 1.1 & 1.1 & & \\
Salt & 0.1 & 0.1 & & \\
\hline
\end{tabular}

\subsection{Proximate and Energy Analysis of Flours and Cookies}

Proximate composition of individual flours and cookies were performed in triplicate following the Association of Official Analytical Chemists standard protocols [29]. Chemical composition analyses were carried out for investigating moisture, ash, fat, crude protein and fiber contents in the samples. Total protein was determined by the Kjeldahl procedure (AOAC 976.05, N × 6.25) (Kjeltec 8200, FOSS Centro América, S.A de C.V., Mexico); fat by Soxhlet extraction (AOAC 920.39) (Soxtec model 2055, FOSS Centro América, S.A. de C.V., Mexico); crude fiber by gravimetric method (AOAC 962.09) (Velp 
Scientifica Fiber Raw Extractor, Velp Scientific, Inc., Bohemia, NY, USA); ash by muffle furnace dry ashing at $550{ }^{\circ} \mathrm{C}$ for $24 \mathrm{~h}$ (AOAC 942.05) (Felisa ${ }^{\circledR}$ model FE 3C1, series 09110120, Jalisco, México), and total carbohydrate by difference, subtracting 100 from the sum of the other components. Energy content of the flours and cookies were determined using a Parr calorimeter model 6400 (Parr Instruments Co., Moline, IL, USA) and the results were express as $\mathrm{kcal} / 100 \mathrm{~g}$.

Moisture content was determined in a thermogravimetric balance (Moisture Analyzer MB45, OHAUS Corp., Parsippany, NJ, USA) by desiccation of $1 \mathrm{~g}$ sample at 100 ${ }^{\circ} \mathrm{C}$ for $10 \mathrm{~min}$. Water activity ( $\mathrm{a}_{\mathrm{w}}$ ) was determined by a portable aw meter (ROTRONIC ${ }^{\circ}$ HygroPalm HP23-AW, ROTRONIC AG, Bassersdorf, Switzerland).

\subsection{Determination of Total Phenolics and Flavonoid Contents in Flours and Cookies}

One gram of flours and cookies were extracted by occasional shaking with 70:29.5:0.5 mixture of acetone-water-acetic acid $(10 \mathrm{~mL})$ at $37^{\circ} \mathrm{C}$ for $60 \mathrm{~min}$ in the dark. Supernatant was obtained by centrifugation at $4000 \mathrm{rpm}$ for $30 \mathrm{~min}$ at $4{ }^{\circ} \mathrm{C}$ (Eppendorf 5702, Eppendorf North America Inc., Framingham, MA, USA). The extraction was repeated by adding 5 $\mathrm{mL}$ of the solvent mixture and the supernatants were mixed and collected in individual vials and stored at $-20^{\circ} \mathrm{C}$ until use.

Total phenolic compounds (TPC) of extracts were determined according to the procedure reported by Singleton and Rossi [30] as described by Ramirez-Sánchez et al. [31]. An aliquot of diluted extracts $(10 \mu \mathrm{L})$ was mixed with Folin-Ciocalteu's phenol reagent at 10 -fold dilution $(75 \mu \mathrm{L})$ and allowed to react for $5 \mathrm{~min}$ in the dark. Sodium carbonate solution $(75 \mathrm{~g} / \mathrm{L}, 75 \mu \mathrm{L})$ was added, and the mixture was shaken. After reacting for $90 \mathrm{~min}$ at room temperature in dark, absorbance was measured at $725 \mathrm{~nm}$ in an Epoch microplate spectrophotometer (Biotek Instruments Inc., Winooski, VT, USA). The results are expressed as $\mu \mathrm{g}$ of gallic acid equivalents per gram of sample, $\mu \mathrm{g}(\mathrm{GAE}) / \mathrm{g}$.

Total flavonoids (TF) in extracts were determined according to the procedure of Zhishen et al. [32]. An aliquot of extracts $(10 \mu \mathrm{L})$ was mixed with $3 \mu \mathrm{L}$ of a $5 \% \mathrm{NaNO}_{2}$ solution and allowed to react for $6 \mathrm{~min} .10 \% \mathrm{AlCl}_{3}(3 \mu \mathrm{L})$ was added and the mixture was left to react for $5 \mathrm{~min}$. Afterwards, $20 \mu \mathrm{L}$ of $1 \mathrm{~mol} / \mathrm{L} \mathrm{NaOH}$ solution and $10 \mu \mathrm{L}$ of distilled water were added and absorbance was measured at $510 \mathrm{~nm}$ in an Epoch microplate spectrophotometer (Biotek Instruments Inc., Winooski, VT, USA). The results were expressed as $\mu \mathrm{g}$ of epicatechin equivalents per gram of sample, $\mu \mathrm{g}(\mathrm{ECE}) / \mathrm{g}$.

\subsection{Evaluation of Antioxidant Activity}

The ABTS*+ scavenging ability of extracts prepared from flours and cookies was determined by the procedure reported by Re et al. [33]. A stock solutions of ABTS*+ cation radical was produced by the reaction between $7 \mathrm{mM}$ water solution of $\mathrm{ABTS}^{{ }^{+}}$and 2.45 $\mathrm{mM}$ potassium persulfate (1:1). The obtained solution was stored at room temperature in the dark for 12-16 $\mathrm{h}$ before use. The ABTS ${ }^{*}$ radical solution was diluted with methanol to reach an absorbance of $1.1 \pm 0.02$ at $734 \mathrm{~nm}$ when using a microplate reader Epoch spectrophotometer (Biotek Instruments Inc., Winooski, VT, USA). Ten $\mu \mathrm{L}$ of each sample was mixed with $190 \mu \mathrm{L}$ of $\mathrm{ABTS}^{+}$solution and allowed to react for $2 \mathrm{~h}$ in the dark. The $\mathrm{ABTS}^{*+}$ radical scavenging activity was evaluated by measuring the absorbance at $734 \mathrm{~nm}$. The antioxidant $(\mathrm{AO})$ capacity was expressed as percentage of decolorization of the $\mathrm{ABTS}^{*}$ radical:

$$
\%=(\mathrm{AR}-\mathrm{AS}) / \mathrm{AR} \times 100
$$

where $\mathrm{AR}=\mathrm{Absorbance}$ of $\mathrm{ABTS}^{*}$ Solution and AS=Sample's Absorbance. 


\subsection{Microbiological Analysis}

Microbiological analysis was carried out in agreement with the Mexican Official Standards NOM-247-SSA1-2008 [34], in particular the specifications for cereals and their products. The samples $(10 \mathrm{~g})$ were randomly selected from each formulation of fortified cookies and aseptically removed using a flame-sterilized device. Each sample was mixed with $90 \mathrm{~mL}$ sterile peptone water $0.1 \%$ (Merck, Darmstadt, Germany) and serial dilutions were made to $10^{4}$ dilutions. The dilutions were analyzed for aerobic mesophilic microorganisms (NMX-F-253), and yeasts and moulds (NMX-F-255).

\subsection{Statistical Analysis}

All experimental data were expressed as mean \pm standard deviation (SD) of triplicate determinations. One-way analysis of variance (ANOVA) followed by the Tukey HSD test was used to determine the significance of differences between formulations at $p<0.05$. All statistical analyses were performed with SPSS version 22.0 (SPSS Inc, Chicago, Il, USA) software package for Windows.

\section{Results}

\subsection{Production and Analysis of Biofunctional Flours}

All-natural oyster mushroom, nopal and amaranth flours were produced by dehydration followed by grinding to the desired particle size of $0.71 \mathrm{~mm}$ as the average value determined by sieving, considered as a coarse fraction $(>0.15 \mathrm{~mm})$ [35]. The chemical composition of whole wheat flour (WWF) and biofunctional flours is presented in Table 2. The wheat and alternative flours used for cookies production differed significantly $(p<0.05)$ in the content of basic proximate components. Our results showed that $\mathrm{POF}, \mathrm{NF}$ and $\mathrm{AF}$ were rich in crude protein, crude fiber and ash, but lower in carbohydrate than WWF. It is noteworthy that POF, NF and AF had approximately 1.46, 1.16 and 1.11-fold higher levels of protein and 5.21, 3.49 and 1.6-fold higher levels of fiber than those of WWF, respectively. The higher ash content in biofunctional flours implied that they contained relatively higher mineral content, in the order NF $>$ POF $>$ AF with values 12, 5.14 and 1.96-fold higher than WWF. AF had the highest lipid and carbohydrate content $(7.26 \%$ and $65.34 \%$, respectively) and consequently, the maximum energy value; in contrast, the lowest energy value was recorded for NF. Moisture content of POF, NF and AF compared favorably with WWF $(p<0.05)$, thus indicating a positive impact in terms of conservation.

In addition to the high nutritional value, $\mathrm{POF}, \mathrm{NF}$ and $\mathrm{AF}$ also possess a significant polyphenols content, decreasing in the order $\mathrm{NF}>\mathrm{AF}>\mathrm{POF}$ with values 8.6, 1.47 and 1.16 times higher than WWF $(p<0.05)$. Flavonoids were especially higher in NF $(64.72 \pm 2.70$ $\mu \mathrm{g} \mathrm{ECE/g)}(p<0.05)$, and lower values were obtained for the rest of the samples. NF and POF exerted a prominent scavenging activity against $\mathrm{ABTS}^{*+}$ radical, about 1.1 times higher than control. 
Table 2. Proximal composition, energy value, phenolic and flavonoid contents, and antioxidant activity of WWF and the three alternative flours obtained from functional ingredients used in cookies' formulation.

\begin{tabular}{|c|c|c|c|c|}
\hline Parameter & WWF & POF & NF & AF \\
\hline Moisture (\%) & $9.76 \pm 0.03^{\mathrm{a}}$ & $8.36 \pm 0.29^{b}$ & $6.34 \pm 0.21^{c}$ & $3.34 \pm 0.45^{\mathrm{d}}$ \\
\hline Water activity $\left(\mathrm{a}_{\mathrm{w}}\right)$ & $0.38 \pm 0.03^{\mathrm{a}}$ & $0.37 \pm 0.01^{a}$ & $0.34 \pm 0.02^{\mathrm{a}}$ & $0.16 \pm 0.00^{\mathrm{b}}$ \\
\hline Total protein $(\%)$ & $16.37 \pm 0.10^{\mathrm{d}}$ & $23.96 \pm 0.18^{a}$ & $18.99 \pm 0.19^{\mathrm{b}}$ & $18.21 \pm 0.05^{\mathrm{c}}$ \\
\hline Carbohydrates (\%) & $68.45 \pm 1.42^{\mathrm{a}}$ & $49.28 \pm 0.49^{b}$ & $50.09 \pm 0.62^{b}$ & $65.34 \pm 1.02^{\mathrm{a}}$ \\
\hline Total lipids (\%) & $2.07 \pm 0.41^{b}$ & $1.04 \pm 0.39^{\mathrm{b}}$ & $1.16 \pm 0.41^{b}$ & $7.26 \pm 1.94^{\mathrm{a}}$ \\
\hline Crude fiber (\%) & $1.99 \pm 0.20^{\mathrm{c}}$ & $10.37 \pm 1.65^{\mathrm{a}}$ & $6.95 \pm 1.70^{\mathrm{a}}$ & $3.18 \pm 0.10^{b}$ \\
\hline Ash (\%) & $1.36 \pm 0.02^{\mathrm{d}}$ & $6.99 \pm 0.17^{b}$ & $16.47 \pm 0.14^{\mathrm{a}}$ & $2.67 \pm 0.10^{c}$ \\
\hline $\begin{array}{l}\text { Energy value } \\
(\mathrm{kcal} / 100 \mathrm{~g})\end{array}$ & $414 \pm 3^{c}$ & $435 \pm 2^{b}$ & $376 \pm 0^{\mathrm{d}}$ & $465 \pm 0.00^{\mathrm{a}}$ \\
\hline $\begin{array}{l}\text { Total polyphenols } \\
\quad(\mu \mathrm{g} \text { GAE/g) }\end{array}$ & $516.3 \pm 11.07^{c}$ & $599.3 \pm 97.42^{b, c}$ & $4452 \pm 46.50^{\mathrm{a}}$ & $759 \pm 17.71^{\mathrm{b}}$ \\
\hline $\begin{array}{l}\text { Total flavonoids } \\
\qquad(\mu \mathrm{g} \text { ECE/g) }\end{array}$ & $11.25 \pm 0.30^{\mathrm{b}}$ & $12.52 \pm 6.90^{b}$ & $64.72 \pm 2.70^{\mathrm{a}}$ & $9.97 \pm 0.90^{\mathrm{b}}$ \\
\hline $\begin{array}{c}\text { Antioxidant } \\
\text { activity (\%, ABTS assay) }\end{array}$ & $88.73 \pm 3.11^{b}$ & $93.48 \pm 2.61^{a, b}$ & $96.30 \pm 0.10^{\mathrm{a}}$ & $77.52 \pm 1.74^{\mathrm{c}}$ \\
\hline
\end{tabular}

Different superscripts indicate significant differences of means for each parameter, according to a one-way ANOVA followed by a Tukey's HSD (honestly significant difference) test $(p<0.05, \mathrm{n}=3)$. 


\subsection{Production of Fortified Cookies with POF/NF/AF}

In order to demonstrate POF, NF and AF applicability in confectionery products fortification, an attempt was made to add more value to standard cookies, by replacing up to $50 \%$ of wheat flour. Figure 2 shows representative photographs of doughs (a), obtained cookies (b), and microscopical appearance of cookies at 40x magnification (c). Results on the physical characteristics of fortified cookies samples at all formulations showed similar weights $(4.3 \pm 0.2 \mathrm{~g})$, determined using an analytical electronic balance, without significant difference with the control cookies. Color is an important visual parameter of cookies. All fortified cookies were found to be darker, particularly those with the highest nopal content (formulations 2 and 1 with $15 \%$ and $10 \%$, respectively), and could be easily distinguished from the WWF control samples. As cladodes powder substitution level increased, the yellow color decreased toward a greenish brown color. This could be explained mainly by the richness of cladodes powder in chlorophylls [36] and the browning of POF/NF/AF carbohydrates during baking.

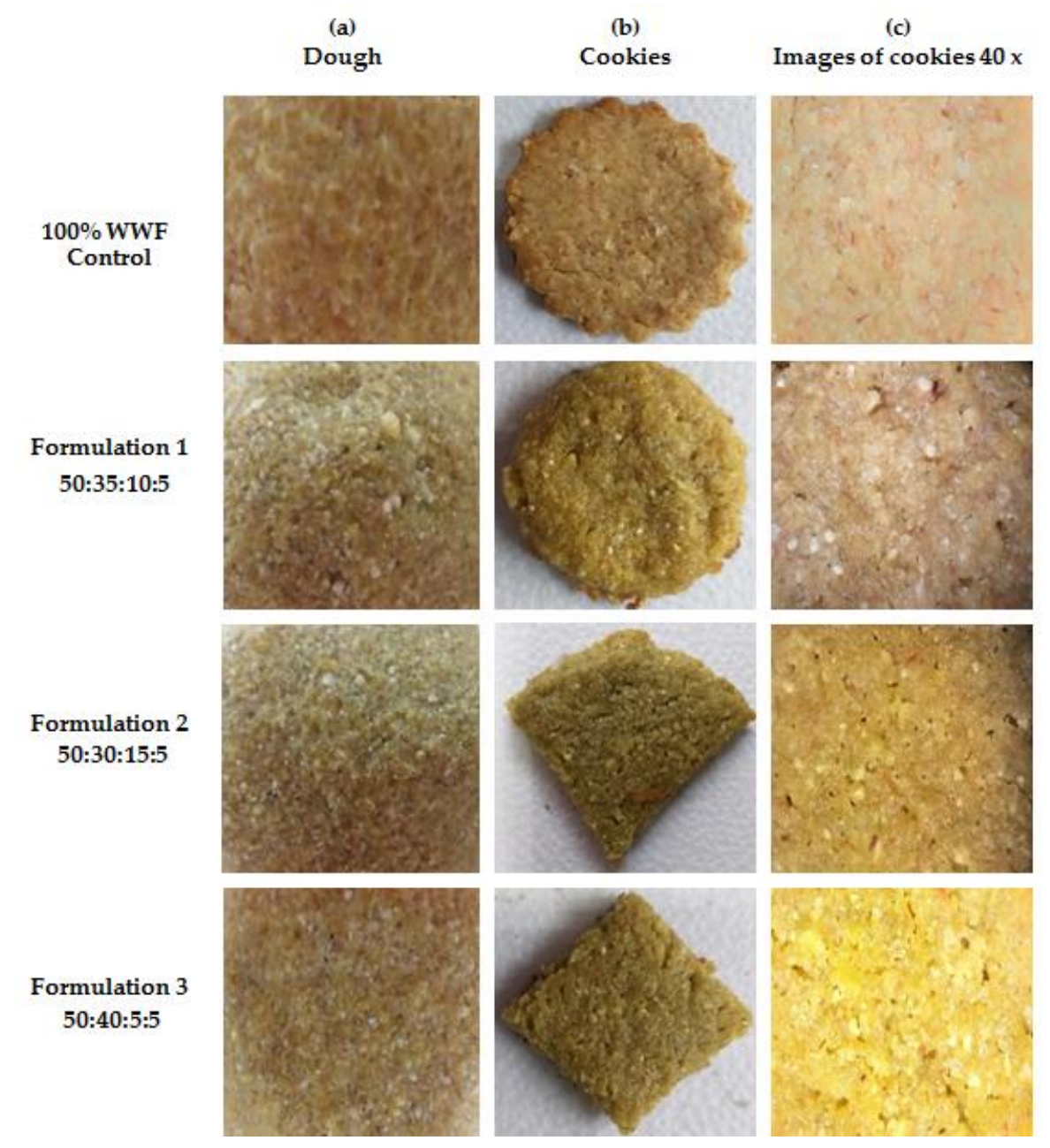

Figure 2. Representative photographs of doughs (a), obtained cookies (b), and microscopical appearance of cookies at 40x magnification under Olympus SZ4045 Stereo Microscope (c) for control and enriched cookies. The proportion of flours' ingredients is indicated for each formulation as whole wheat:amaranth:nopal:Pleurotus ostreatus flours (WWF:AF:NF:POF).

\subsection{Functionality of Fortified Cookies}

Level of enrichment of the cookies, i.e., functional characteristics of fortified cookies was determined based on an increase of nutrients and myco/phytochemicals content and 
antioxidant activity. Significant improvement of conventional cookies functionality through the incorporation of $\mathrm{POF} / \mathrm{NF} / \mathrm{AF}$ was confirmed.

\subsubsection{Nutritional Content}

The results obtained for proximal composition of the cookies prepared from different blends of wheat and alternatives flours are depicted in Table 3. An increase was observed in moisture content among the fortified cookies compared to control cookies $(p<0.05)$. However, all the samples were shown to have aw values of less than 0.5 , which means that all cookies formulations had a low percentage of free water for microbial proliferation, leading to a high stability product [37].

Fortified cookies had approximately 1.2-fold higher levels of protein and between 1.58-2.1 fold higher levels of ashes than those of the wheat flour (especially in formulations 2 and 1 rich in nopal) $(p<0.05)$. When biofunctional flours were incorporated into cookies, a reduction of carbohydrates was observed coincidental with the increase in protein content. Cookies prepared with F 2 (15\% nopal) contained 5.29\% of dietary fiber, 2.1 -fold higher than control $(p<0.05)$. The result of the lipid content showed no significant differences among fortified cookies; only formulation two had a relatively slight decrease compared to control cookies $(p<0.05)$. The energy values $(542-590 \mathrm{kcal} / 100)$ did not show significant differences among cookies samples. The lowest energy value was recorded for WWF control cookies.

\subsubsection{Content of Dietary Polyphenols and Flavonoids}

Table 3 shows the total phenolic and flavonoid content of the fortified cookies. Those made with $100 \%$ whole wheat flour had the lowest total phenolic and flavonoid levels of all samples. As expected, POF/NF/AF substituted for wheat flour enhanced the total phenolic and flavonoid content significantly in the fortified cookies samples $(p<0.05)$. It is noteworthy that formulations 2, 1 and 3 had approximately 5.02, 3.81 and 2.49-fold higher levels of polyphenols than those of control cookies. No significant differences were found in flavonoid content between biofunctional cookies, but the values were greater than traditional cookies $(p<0.05)$, ranging from 1.77 to 2.59-times higher in formulations 3 and 2, respectively. Particularly, cookies prepared with F 2 possessed the highest content of total phenolic and flavonoid in agreement with the added nopal level.

\subsubsection{Antioxidant Activity}

In this study, the radical scavenging activity towards artificial radical $\mathrm{ABTS}^{{ }^{+}}$species was explored to evaluate the antioxidant properties of cookie samples. The application of this method is wide due to its numerous modifications and it can be applied in antioxidant activity determination in both lipophilic and hydrophilic antioxidants, including food samples [38]. Therefore, it is a suitable technique to clarify the impact of POF/NF/AF on the potential functional properties of fortified cookies. The antioxidant activity of different cookie samples effect is shown in Table 3. The ABTS ${ }^{*}$ scavenging ability was similar in the three enriched cookies formulations $(87.73-89.58 \%)$ but as average 1.2-times higher than traditional cookies $(75.60 \%)(p<0.05)$.

\subsection{Microbiological Analysis}

Microbiological analysis showed that all cookies formulations were within the permissible limits, according to the Mexican legislation (Table 4). These microorganisms are indicators of management conditions or efficiency of the food preparation. They timely warn of inadequate handling or contamination that increases the risk for the presence of pathogenic microorganisms in the product [39]. 
Table 3. Proximal composition, energy value, phenolic and flavonoid contents, and antioxidant activity of traditional WWF cookies and those produced with different formulations of alternative flours from functional ingredients.

\begin{tabular}{|c|c|c|c|c|}
\hline Parameter & Traditional cookies & Formulation 1 & Formulation 2 & Formulation 3 \\
\hline Moisture (\%) & $2.65 \pm 0.15^{b}$ & $3.16 \pm 0.15^{a}$ & $3.32 \pm 0.04^{a}$ & $3.29 \pm 0.01^{a}$ \\
\hline Water activity $\left(\mathrm{a}_{\mathrm{w}}\right)$ & $0.41 \pm 0.01^{\mathrm{a}, \mathrm{b}}$ & $0.44 \pm 0.02^{\mathrm{a}}$ & $0.33 \pm 0.08^{b, c}$ & $0.25 \pm 0.01^{c}$ \\
\hline Total protein $(\%)$ & $7.07 \pm 0.08^{b}$ & $8.17 \pm 0.36^{\mathrm{a}}$ & $8.18 \pm 0.23^{a}$ & $7.93 \pm 0.19 a$ \\
\hline Carbohydrates (\%) & $52.62 \pm 1.24^{a}$ & $50.37 \pm 0.48^{b}$ & $48.07 \pm 0.66^{c}$ & $51.11 \pm 1.52 \mathrm{a}, \mathrm{b}$ \\
\hline Total lipids (\%) & $34.10 \pm 0.14^{a}$ & $33.32 \pm 0.54 \mathrm{a}, \mathrm{b}$ & $33.13 \pm 0.25^{b}$ & $33.58 \pm 0.17 \mathrm{a}, \mathrm{b}$ \\
\hline Crude fiber (\%) & $2.58 \pm 0.53^{b}$ & $3.11 \pm 0.12^{b}$ & $5.29 \pm 1.45^{\mathrm{a}}$ & $2.54 \pm 1.60^{b}$ \\
\hline Ash (\%) & $0.98 \pm 0.03^{c}$ & $1.87 \pm 0.05^{\mathrm{a}}$ & $2.01 \pm 0.07 \mathrm{a}$ & $1.55 \pm 0.06^{b}$ \\
\hline $\begin{array}{l}\text { Energy value } \\
(\mathrm{kcal} / 100 \mathrm{~g})\end{array}$ & $542 \pm 37$ & $586 \pm 20$ & $583 \pm 10$ & $590 \pm 10$ \\
\hline $\begin{array}{l}\text { Total polyphenols } \\
(\mu \mathrm{g} \text { GAE } / \mathrm{g})\end{array}$ & $272.1 \pm 15.50^{\mathrm{d}}$ & $1036 \pm 42.07 \mathrm{~b}$ & $1366 \pm 92.99 a$ & $677.6 \pm 70.85^{c}$ \\
\hline $\begin{array}{l}\text { Total flavonoids } \\
\quad(\mu \mathrm{g} \text { ECE } / \mathrm{g})\end{array}$ & $3.60 \pm 2.70^{b}$ & $8.91 \pm 1.80^{a}$ & $9.33 \pm 1.20^{a}$ & $6.36 \pm 3.00^{a}$ \\
\hline $\begin{array}{c}\text { Antioxidant } \\
\text { activity }(\%, \text { ABTS assay })\end{array}$ & $75.60 \pm 2.07^{b}$ & $89.58 \pm 1.65^{a}$ & $88.82 \pm 0.83$ a & $87.73 \pm 1.10^{a}$ \\
\hline
\end{tabular}

Different superscripts indicate significant differences of means for each parameter, according to a one-way ANOVA followed by a Tukey's HSD (honestly significant difference) test $(p<0.05, \mathrm{n}=3)$. 
Table 4. Microbial counts of mesophilic microorganisms, yeasts and moulds in traditional WWF cookies and those produced with different formulations of alternative flours from functional ingredients.

\begin{tabular}{lccccc}
\hline $\begin{array}{c}\text { Determination } \\
(\text { CFU/g) }\end{array}$ & $\begin{array}{c}\text { Traditional } \\
\text { cookies }\end{array}$ & F 1 & F 2 & F 3 & $\begin{array}{c}\text { Limits [34 ] } \\
\text { (CFU/g) }\end{array}$ \\
\hline $\begin{array}{l}\text { Aerobic mesophilic } \\
\text { microorganisms }\end{array}$ & $<10$ & 20 & 30 & 20 & $1 \times 10^{4}$ \\
Yeasts & $<10$ & $<10$ & $<10$ & $<10$ & 300 \\
Moulds & $<10$ & $<10$ & $<10$ & $<10$ & 300 \\
\hline
\end{tabular}

\section{Discussion}

The development of new fortified flour products have a demanding task capable of influencing metabolism and other health-related conditions. One of the categories of functional additions are components with antioxidative properties, which can reduce the level of oxidative stress in cells [40]. In this context, the effect of different amounts (5-95\%) of food components as well as agro-industrial by-products such as banana flour [41], rapeseed press cake [40], soybean meal [42], apple pomace flour [27], spices and herbs [43], prickly peel fruits [44], mushrooms [45], among others, has been analyzed recently on the antioxidant capacity (AO) of biscuits and cookies.

Most of the time, cookies and biscuits are prepared using refined wheat flour, but composite flour is healthier because it improves the nutritional value of bakery products when blended with other types of flour [41]. Innovation in products with high cultural value could be an important factor for greater consumer acceptance. Studies in this regard are necessary in the development of functional foods/nutraceuticals appealing to different populations. In this sense, the development of cookies enriched with oyster mushroom, nopal and amaranth flours is suitable due to the nutritional and health-promoting properties of these prehispanic Mexican food products. Thus, fortified cookies with $\mathrm{POF} / \mathrm{NF} / \mathrm{AF}$ offers the possibility of introducing substances including antioxidant molecules with beneficial properties for health through the diet.

The use of POF, NF and AF as natural raw materials to enhance the functional properties of bakery products is not a quite common practice. Its incorporation into bakery products has been reported individually for the partial replacing of wheat flour, e.g. oyster mushroom Pleurotus at levels of $4-30 \%$ (suggested percent of powder substitution of $5-8 \%$ in terms of flour basis) [13,45]; for nopal flour at levels of $4-15 \%$ $[16,46,47]$; and for amaranth at levels of $20-100 \%[48,49]$. To our knowledge, this is the first study to report the development of a novel wheat and POF/NF/AF blend cookies with improved nutritional and functional attributes with respect to control cookies. The levels in which the biofunctional flours were incorporated into doughs are in agreement with the studies aforementioned.

The information about the proximate composition and energy is of great interest for biofunctional ingredients to be used in the formulation of health foods and nutraceuticals. Information about the complete characterization of flours will allow not only to establish possible combinations between them with the aim to enhance the nutritional profile of the bakery products, but also to be used in other types of products, such as beverages, soups, sauces, or food adjuvants [50]. The wheat and biofunctional flours used for cookies production differed significantly in the content of basic proximate components (Table 2) and POF, NF and AF showed a better nutritional profile compared to commercial WWF. They are all rich in proteins, fibers, and ashes contents, in contrast to low fat levels (excepting amaranth), which make them suitable to incorporate into low caloric 
confectionery products. Even if there was variability on the chemical composition values of the selected flours with those obtained by other researchers, the proximate biochemical analysis of POF, NF and AF is in agreement with the composition informed in previous reports.

For oyster mushroom Pleurotus ostreatus ranges between 17-30.4\% for crude protein, $37-85 \%$ for carbohydrates, $5.3-24 \%$ for total dietary fiber, $1.6-5.0 \%$ for fat and $5.9-9.8 \%$ for ash have been reported [45,51,52] depending on the strains, method of cultivation, substrates and growth conditions, etc. On the other hand, nopal chemical composition is not absolute and may vary according to variety, soil factors, cultivation season, and plant age, in intervals between $7.07-19.0 \%$ for crude protein, 38-61.4\% for carbohydrates, 5.97 $55.05 \%$ for total dietary fiber, $0.1-2.16 \%$ for fat and $14.4-23.05 \%$ for ash $[16,21,47]$. In addition, the values obtained for AF composition are consistent with those reported in the bibliography in ranges between $12.4-21 \%$ for crude protein, $48-69 \%$ for carbohydrates, 3$20.6 \%$ for total dietary fiber, $3.24-8.6 \%$ for fat and $2.6-3.8 \%$ for ash, also varying with varieties and several ecological factors $[48,49,50,53,54]$.

Additionally, the obtained POF, NF and AF are vehicles for the delivery of bioactive substances including antioxidant molecules, such as polyphenols/flavonoids (Table 2). These molecules are considered to be of high scientific and therapeutic interest, because they help to prevent degenerative diseases, cardiovascular diseases and cancers, among others [55]. The content of phenolics is commonly determined by the Folin-Ciocalteu reaction. However, the comparison of our results with data regarding total phenolic/flavonoid content in literature is difficult because different extraction solvents and substances for calibration are used and data are variously expressed in quercetin (Q), catechin (C), gallic (GA), or other compound equivalents (E). Moreover, different methods have been used for measuring antioxidant activity based on diverse chemistry principles [56]. TPC was higher in the three biofunctional flours compared to WWF, but a significant FC was shown only in NF. Although different studies reported that the antioxidant capacity is strongly related to the phenolic profile in diverse food products [50,57], in our study a direct relation between TPC and AO was found only for NF, which displayed the highest $\mathrm{AO}$ in the $\mathrm{ABTS}^{*}+$ assay followed by POF.

Despite the great extent of variability regarding TPC, FC and AO of the examined flours (and/or their sources) described in the literature, our results in general are in line with other reports. The TPC of POF tested in the present work was $599.3 \pm 97.42 \mu \mathrm{g} / \mathrm{g}$, comparatively higher than the values reported in five wild culinary-medicinal species of Pleurotus collected from Northwest India (67.6 to $169.2 \mu \mathrm{g} / \mathrm{g}$ ) [58]. In other study, the content of total phenols was determined in five extracts of $P$. ostreatus powder obtained with solvents of different polarity. The content of polyphenols in extracts decreased in the order: water $>$ ethanol $>$ acetone $>$ ethyl acetate $>$ n-hexane [59]. TPC of POF was lower than those reported for water and ethanol (1 384 and $863.7 \mu \mathrm{g} / \mathrm{g}$, respectively) but higher than values reported in less-polar solvents. These findings are consistent with the solvent mixture used for extracting polyphenols in our study, acetone-water-acetic acid (70:29.5:0.5). Lower values were obtained for FC in POF compared to a previous report, in which 5.46 and $3.58 \mathrm{mg}$ CE/100 g were reported for fruiting bodies and primordia of $P$. ostreatus, respectively [11]. In this study, $\mathrm{ABTS}^{++}$radical scavenging activity of POF $(93.48 \%)$ was higher than preparations from $P$. ostreatus fruiting bodies and mycelium previously investigated with values of 80 and 55\%, respectively [9].

On the other hand, all plant parts of nopal (flowers, pulp, seeds, skin, and leaves) are rich in phenols: flavols, flavones, phenolic acids, etc. [18]. The TPC of NF tested in the present work was $4452 \pm 46.50 \mu \mathrm{g} / \mathrm{g}$, comparatively higher than the values between 562 $905 \mu \mathrm{g}$ GAE/g and 570-2300 $\mu \mathrm{g}$ GAE/g reported in nopal flour and dehydrated nopal, respectively [60] and in the range of 1240-5410 $\mu \mathrm{g}$ GAE/g [61]. However, lower values were obtained for TPC in NF with respect to by-products of nopal cladodes (2.7-3.7 $\mathrm{g}$ GAE/100 g) [62] and in cladodes after convective drying at $45^{\circ} \mathrm{C}$ (40.97 $\mathrm{g}$ of phenols/kg of 
samples) [63]. In this study, NF had a low FC (64.72 $\pm 2.70 \mu \mathrm{g}$ ECE/g) compared to other reports $[61,63,64]$. When compared to fresh cladodes, nopal powders/flours had lower flavonoid content, which is probably related to the effect of temperature/time of drying of the material on the degradation of chemical compounds like flavonoids [65] or collection periods because of the response of the cultivars to the flavonoids was more intense in the rainy period [61]. The antioxidant capacity of cladodes has been assessed both in vitro and in vivo. Differences reported might have arisen from different methodologies and Opuntia samples used in different studies. In our study, NF exerted a prominent scavenging activity against ABTS $^{*+}$ radical (96.30\%). Dehydrated nopal and cladodes by-products showed $\mathrm{ABTS}^{\cdot+}$ radical scavenging activity with values of 6.11 and between $52-57 \mu \mathrm{mol}$ Trolox E/g, respectively $[60,62]$.

Several studies have focused on polyphenols in amaranth species, and have resulted in the identification of many phenolic acids and flavonoids. The TPC in AF found in this work $(759 \pm 17.71 \mu \mathrm{g}$ GAE/g) is above the values reported in amaranth seeds from $A$. hypochondriacus extracted with methanol, ethanol, and hexane by means of Soxhlet and magnetic stirring, which varied between 160-250 $\mu \mathrm{g}$ GAE/g [66] and higher than a commercial AF (<500 $\mu \mathrm{g}$ GAE/g) [50]. The abundance of flavonoids in amaranth has been confirmed and is highly affected by methodology, especially extraction solvent. Extraction with hot water obtained much higher yields of total phenolic compounds $(4.23 \pm 1.00 \mathrm{mg}$ GAE/g), but the concentration of flavonoids decreased remarkably to $0.08 \pm 0.00 \mathrm{mg} \mathrm{CE} / \mathrm{g}$ [67]. The predominance of rutin and very low levels of nonglycosylated flavonoids among the phenolic compounds is responsible for the low antioxidant potential of amaranth seeds [53]. A significant antioxidant activity was described for a methanolic extract of $A$. caudatus in all the studied in vitro antioxidant models; however, it was extremely effective in scavenging $\mathrm{ABTS}^{*}$ radical activity ( $\left.\mathrm{IC}_{50} 48.75 \pm 1.1 \mu \mathrm{g} / \mathrm{mL}\right)$ [68]. In our study, although the TPC was reasonably high, lower antioxidant activity, average $77.52 \pm 1.74 \%$, was measured. These findings are consistent with a previous report, in which amaranth showed a lower antioxidant activity (average $3.26 \mathrm{mmol} \mathrm{TE} / \mathrm{kg}$ ) compared to quinoa, whereas its TPC was higher. Thus, no significant correlation between phenolics and antioxidant potential was observed [69]. Contradictory, other studies informed that in vitro antioxidant capacity correlated well with the amount of phenolics among cereals, pseudocereals and legumes [50,57].

Biscuits/cookies are considered as a type of confectionary with low moisture content and can serve as a vehicle tool for important nutrients if made readily available to the population [70]. Moisture content and water activity are crucial parameters to predict both the stability and safety of the product, with great impact in conservation [37]. In terms of moisture, there are significant differences in content between biofunctional flours (3.34\% in AF to 8.36\% in POF) lower values than WWF (Table 2), in line with the informed in previous reports: $7.04-10.6 \%$ for POF [13,45], 4.70-13.33\% for NF [47,60,64] and 4-9.07\% for AF $[48,50,54]$. Moisture content is an index of storage of the flours. These low moisture contents of flours would be due to the efficiency of the drying methods used. Indeed, it is well established that high moisture superior at $12 \%$ of food products promotes susceptibility to microbial growth and enzyme activity which accelerates spoilage [71]. The moisture content of the composite cookies (3.16-3.32\%) were statistically higher than WWF cookies $(2.65 \%$ ) (Table 3$)$, but within the recommended range of $0-10 \%$ for storage of biscuits [44], and the aw values were lower than 0.5. This is advantageous because reduction in moisture content of baked products will reduce the proliferation of spoilage organisms especially moulds, thus, improving the shelf stability of the product. The present results compared favorably with other studies on WWF cookies fortified with the individual flours, e.g. oyster mushroom (3.97-9.63\% at inclusion levels from 5 to 30\%) [45], nopal (3.48\% at $4 \%$ level) [44], and amaranth, which showed the highest humidity of $12.8 \%$ at $24 \%$ of inclusion [49]. 
Collectively, the differences in nutritional composition of cookies samples in this study are related to the original chemical compositions of wheat and POF, NF and AF, along with their relative inclusion level in the recipe. In this recipe the $61.4 \%$ of the ingredients corresponds to margarine and sugar; therefore, the content of nutrients in composite cookies is relatively lower than in former POF, NF and AFs. As sugar and wheat flour are added in cookies preparation, the carbohydrate content in cookies should be higher than flours. But the occurrence of Maillard reaction in the baking process had decreased the carbohydrate content in cookies compared to flours. The products of the Maillard reaction are able to affect the antioxidant capacity of bakery foods [72]. The Maillard reaction products formed during the production of cookies could also act as antioxidants and scavenge free radicals [73], which consequently contribute to better antioxidant activity of the cookies.

The replacement of the $50 \%$ of WWF by different levels of POF, NF and AF in fortified cookies resulted in an increase in some nutrients: $12-16 \%$ of protein, $58-105 \%$ of ashes (especially in formulations 2 and 1 rich in nopal), and 2 times the amount of dietary fiber in formulation 2, compared to the control (Table 3).

In other studies, protein content ranged from $11.07-15.55 \%$ in biscuits fortified with $5 \%$ up to $30 \%$ of the oyster mushroom [13,74], 8.47-10.26\% of cookies enriched with $1-5 \%$ of mushroom (Cordyceps militaris) flour [75], and 18.7\% in cookies enriched with $24 \%$ of amaranth flour [49]. Similar results were also reported in the protein content of cookies with the addition of sclerotium flour of edible mushroom Pleurotus tuber-regium, which was significantly higher than that of control cookies [76]. In contrast, relatively slight but not significant changes in protein content of cookies was observed when wheat flour was substituted by cladodes powder at 2.5 to $7.5 \%$ (9.08-9.20\% in supplemented cookies vs. $9.26 \%$ in control) [64]. In our work, the three formulations of fortified cookies contained more protein than WWF cookies, which may be a reason for predicting a reduced glycemic response of the $\mathrm{POF} / \mathrm{NF} / \mathrm{AF}$ enriched cookies. A reduction of carbohydrates was observed coincidental with the increase in protein content when biofunctional flours were incorporated into cookies. It has been observed that even small amounts of protein in food products were enough to alter the starch digestibility and other functional properties, thus limiting starch degradation and sugar liberation [72]. Moreover, it is widely known that WFF cookies, commonly available in the market, lack good quality protein because of their deficiency in lysine. For this reason, the production of cookies enriched with POF/NF/AF can increase not only the protein content, but also improves the amino acid balance of the final product, due to the contribution of lysine and other essential amino acids by these biofunctional flours $[56,77,78]$.

Substitution of 50\% WWF by AF:NF:POF (30:15:5) in formulation two had a positive impact in the dietary fiber content of fortified cookies (5.29\% vs. $2.58 \%$ in control cookies). The importance of dietary fiber in food is well known; its consumption has shown benefits throughout the digestive process. Different physiological and prebiotic effects at the colon level make this nutrient a key component of a healthy diet [79]. Dietary fiber in cookies based on formulation 2 represents the 17-21\% DRV/100 $\mathrm{g}$ for women and 15\% DRV/100 $\mathrm{g}$ for men in the group of 31-50 years old vs. the $8.6-10 \% \mathrm{DRV} / 100 \mathrm{~g}$ for women and $7 \%$ $\mathrm{DRV} / 100 \mathrm{~g}$ for men in conventional cookies [79]. However, enriched cookies do not meet the requirements for higher fiber foods -a content $\geq 2.5 \mathrm{~g}$ per one serving (30 $\mathrm{g}$ for cookies) according to nutrients specifications for Mexican people [80]. In addition, the content of dietary fiber in formulation two may also contribute to the overall antioxidant activity of cookies. The substitution of 7, 9 and $11 \%$ of wheat flour with Fibrex ${ }^{\circledR}$ (commercial formulation of sugar beet dietary fiber, Nordic Sugar, Sweden) in the formulation of cookies upgraded the antioxidant activity in the DPPH radical scavenging activity test [73]. A synergistic effect of dietary fiber and antioxidant activity, possibly through carrier bioactive compounds, was reported by incorporating mushroom bioactive compound in bread [72]. In other studies, the incorporation of 5\% prickly pear peel powder into wheat 
flour improved the total fiber content of the biscuits from 5.9 to $8.1 \mathrm{~g} / 100 \mathrm{~g}$ [81], and the dietary fiber levels of biscuits containing oyster mushroom at 5-30\% ranged from 2.10$2.93 \%[13,45]$. A significant increase in dietary fiber content $(0.95-2.42 \%)$ was observed in cookies made with cladodes powder at 2.5 to $7.5 \%$ compared to the control product $(0.40 \%)$ [64]. Substitution of wheat flour by amaranth in bread has had similar results, increased insoluble dietary fiber and ash contents [82].

Ash content represents all the inorganic minerals contained in the sample, which have important biological roles in the organism. Several reports have documented the abundance of minerals in oyster mushroom, nopal and amaranth, such as $\mathrm{Ca}, \mathrm{K}, \mathrm{Mg}, \mathrm{Fe}$, and those with antioxidant functions $-\mathrm{Zn}, \mathrm{Cu}, \mathrm{Mn}$ and Se- which seem to play a protective role in diseases related to oxidative stress $[17,52,54,78]$. The higher ash content of the supplemented cookies indicated that they contained a higher mineral content than the control wheat cookies. These changes were due to the elevated levels of these nutrients, especially within the prickly pear cladodes and the oyster mushroom. The results informed here were comparable to previous reports in cookies made with cladodes powder (1.80-3.21\%) higher than the control product (1.19\%) [64], and biscuits supplemented with oyster mushroom (1.52-3.58\%, level of supplementation 5-30\%) [45]; they were higher than ash content $(0.51-0.62 \%)$ in cookies enriched with $1-5 \%$ of mushroom (Cordyceps militaris) flour [75].

The incorporation of POF/NF/AF into wheat flour significantly improved the TPC and $\mathrm{AO}$ capacity of composite cookies compared to control. In addition, phenolics retain their AO activity after the baking process, which has potential health benefits for consumers, although some authors informed that baking could reduce the TPC in the obtained cookies [43]. TPC was particularly higher in F1 and F 2, which contained the highest NF levels. Antioxidant effect of supplemented cookies was evaluated by ABTS ${ }^{*}$ radical-scavenging activity. Interestingly, enriched cookies exhibited similar AO activity upgraded $17.5 \%$ compared to cookies prepared with $100 \%$ WWF, which displayed the lowest $\mathrm{ABTS}^{\circ}+$ radical scavenging activity. Therefore, no direct correlation was found between TPC and AO activity of fortified cookies. Relatively slight but not significant decreasing was observed in $\mathrm{AO}$ activity of $\mathrm{F} 3$, which contains the highest level of $\mathrm{AF}$-the flour that exhibited the lowest $\mathrm{AO}$ activity. It is worth noting that POF, NF and AF are complex matrixes and the AO may reflect the interactions (synergy or antagonism) among its constituents in addition to phenolics. This AO array contains vitamins and minerals, and for the oyster mushroom dietary fiber -mainly $\beta$-glucans-, polysaccharides, polysaccharide-protein complexes [10,11]; and for nopal and amaranth- dietary fiber, betalains, carotenoids, phytosterols, chlorophylls, among others molecules $[18,21]$.

In other studies, TPC of biscuits fortified with $4 \%$ of prickly pear peel flour (PPF) was $19.1 \mathrm{mg} / \mathrm{g}$ with significant difference between control and composite biscuits. However, addition of PPF significantly reduced $(p<0.05)$ TPC of biscuits. The decrease of TPC was attributed to that baked products drastically reduce levels of phenolic compounds because of the polymerization of polyphenols and decarboxylation of phenolic acids that occur during thermal treatment. An improvement of the overall antioxidant activity (DPPH and ferric-reducing power assay -FRAP- values) was observed with incorporation of PPF into biscuits [44]. On the other hand, at 7.5\% level of cladodes supplementation, cookies exhibited the highest DPPH radical-scavenging activity $(53.29 \%$ on day 1 and $49.43 \%$ on day 30 ) and a comparable trend was also noticed for FRAP [64]. With respect to mushrooms, despite of the methods conducted (DPPH and $\mathrm{ABTS}^{\circ}+$ radical scavenging activity, FRAP and reducing power), the addition of $C$. militaris mushroom flour as source of natural phenolic compounds remarkably increases the antioxidant activities of cookies [75]. In the case of amaranth flour cookies, the DPPH radical scavenging activity of germinated AF cookies was 1.3 and 1.1 times higher than WWF and raw amaranth flour cookies, respectively [48]. 
The differences observed in the studies could be due to different structure of the phenolic compounds that might have influenced the AO activities. The AO activity of the compound structure was reported to be dependent on the number of included active group $(\mathrm{OH})$ and the position of the active groups [56]. Therefore, determination of phenolic profile of cookie samples and correlation analysis between phenolic compounds and antioxidant activities are worthwhile to be studied further.

Polyphenolic compounds in the added biofunctional flours could also act as nonproteinaceous amylase inhibitors, and therefore, the fortified cookies could be promissory for glycemic index decrease, in agreement with the manipulation of the predictive glycemic response associated to phenolic properties of bread by incorporating mushroom bioactive compounds [72].

The POF/NF/AF enriched cookies contained relatively high content of fat $33.13 \%$ in formulation two to $34.10 \%$ in WWF on dry matter basis). Consequently, they are at higher risk of quality degradation in terms of oxidative changes. The addition of natural ingredients bearing antioxidant properties or synthetic antioxidants can extend their shelf life by retarding or inhibiting oxidation reactions. However, synthetic antioxidants like butylated hydroxyanisole (BHA) and butylated hydroxytoluene (BHT) have been reported as controversial with respect to their health safety for utilization in food products [83]. Taking together, our results indicated that supplementation of WFF with POF, NF and $\mathrm{AF}$ in fortified cookies not only reinforces the nutritional quality, but also contributes to their stabilization against oxidative damage. Overall, enriched cookies have more functional components and effective antioxidant capacity than wheat cookies. Their supplementation could provide the consumers a novel product with health-promoting benefits.

\section{Conclusions}

This manuscript comprehensively illustrates the development of novel functional cookies by supplementing WWF with formulations based on Pleurotus ostreatus mushroom, nopal and amaranth flours. In the light of the present data, it can be concluded that partial replacement (50\%) of WWF by biofunctional flours enhanced the nutritional value of cookies in view of the reach nutritional composition comprising polyphenols/flavonoids and a significant antioxidant potential of POF, NF and AF. Total protein, ashes and flavonoids were higher in fortified cookies than controls. Particularly, cookies prepared with F 2 -highest nopal level- contained 5.29\% of dietary fiber and 5times higher polyphenol content than control cookies. Another attractively benefits of POF, NF and AF flours' addition was the enhancement of phenolic content and antioxidant activity of cookies. The ABTS ${ }^{*}$ scavenging ability was similar in the three enriched cookies (87.73-89.58\%) but higher than traditional cookies $(75.60 \%)$ as the result of naturally occurring synergistic myco-/phytonutrients to attain holistic wellbeing. Consequently, cookies supplemented with $\mathrm{POF} / \mathrm{NF} / \mathrm{AF}$ flours had functional advantages over the conventional based WWF cookies, as well as good sanitary attributes for human consumption. Among the three formulations, F 2 cookies (WWF:AF:NF:POF, 50:30:15:5) showed a better nutrient profile for the overall performance.

Thus, the fortification of cookies with these biofunctional flours is an effective tool to offer nutritious, antioxidant-rich and healthy FF/Ns alternatives to consumers. Further studies are needed to evaluate the storability and sensorial acceptance of novel cookies by potential consumers. Additionally, in vivo intervention studies in animal models and humans will be advisable to verify the protective role of fortified cookies in modulating oxidative-stress related conditions. As there are no standard products developed with the combination of these iconic pre-Hispanic foods as functional cookies or other interesting new technological uses, this research promotes Mexican renewable local bioresouces for a sustainable agri-food chain, especially edible mushrooms. 
Author Contributions: Conceptualization, G.U.F., G.G.S., M.M.H.O., M.M.S.O., H.J.M.Q. and M.M.M.; methodology, G.U.F., G.G.S., M.M.H.O., M.M.S.O., H.J.M.Q. and M.M.M.; software, G.U.F. and M.M.M; validation, G.G.S., M.M.H.O., M.M.S.O., H.J.M.Q. and M.M.M.; formal analysis, G.U.F., G.G.S., M.M.H.O., H.J.M.Q. and M.M.M.; investigation, G.U.F., M.M.S.O. and M.M.M.; resources, M.M.M.; data curation, G.U.F., H.J.M.Q. and M.M.M.; writing-original draft preparation, G.U.F. and M.M.M.; writing - review and editing, H.J.M.Q. and M.M.M.; visualization, G.U.F., G.G.S., M.M.H.O., M.M.S.O., H.J.M.Q. and M.M.M.; supervision, M.M.H.O., H.J.M.Q. and M.M.M.; project administration, M.M.M; funding acquisition, M.M.M. All authors have read and agreed to the published version of the manuscript.

Funding: Monetary sponsorship was received from Institutional funding sources through the Project 201517 "Development and characterization of biofunctional cookies formulated with amaranth, nopal and Pleurotus ostreatus mushroom" (Universidad Anáhuac, México).

Institutional Review Board Statement: Not applicable.

Informed Consent Statement: Not applicable.

Data Availability Statement: All data needed to evaluate the conclusion in the paper are present in the manuscript. Additional data related to this study are available on request to the corresponding authors.

Acknowledgment: The authors are grateful to the Centro de Investigación en Ciencias de la Salud (CICSA) and to the Research Direction of Universidad Anáhuac México for the support provided through the institutional project 2011517.

Conflicts of Interest: The authors declare no conflict of interest.

\section{Abbreviations}

aw

Activity of water

ABTS 2,2-azino-bis-(3-ethylbenzothiazoline-6-sulfonic acid)

AF Amaranth flour

AO Antioxidant

BHA Butylated hydroxyanisole

BHT Butylated hydroxytoluene

CE Catechin equivalents

DPPH 1,1-diphenyl-2-picrylhydrazyl radical

DRV Daily Reference Value

ECE Epicatechin equivalents

FF/Ns Functional foods/ nutraceuticals

FRAP Ferric-reducing power assay

GAE Gallic acid equivalents

$\mathrm{IC}_{50}$ Concentration of antioxidants needed to decrease the initial values in antioxidants tests by $50 \%$

NCD Non-communicable diseases

NF Nopal flour

POF Pleurotus ostreatus flour

TF Total flavonoids

TPC Total polyphenol content

SDG Sustainable Development Goals

WWF Whole-wheat flour 


\section{References}

1. Wang, Y.; Wang, J. Modelling and prediction of global non-communicable diseases. BMC Public Health 2020, $20,822$.

2. Global Nutrition Report 2018. Available online: https:/globalnutritionreport.org/reports/global-nutrition-report-2018/ (accessed on 11 September 2021).

3. Bagchi, D.; Swaroop, A.; Bagchi, M. Genomics, proteomics and metabolomics in nutraceuticals and functional foods, 2nd ed.; John Wiley \& Sons, Ltd.: Chichester, UK, 2015; pp. 653.

4. Ríos-Hoyo, A.; Romo-Araiza, A.; Meneses-Mayo, M.; Gutiérrez-Salmeán, G. Prehispanic functional foods and nutraceuticals in the treatment of dyslipidemia associated to cardiovascular disease: a mini-review. Int. J. Vitam. Nutr. Res. 2017, 1-14.

5. Martínez-Carrera, D.; Larqué-Saavedra, A.; Tovar-Palacio, A.; Torres, N.; Meneses, M.E.; Sobal-Cruz, M.; Morales-Almora, P.; Bonilla-Quintero, M.; Escudero-Uribe, H.; Tello-Salgado, I.; González-Teodoro, B.; Martínez-Sánchez, W.; Mayett, Y. Contribución de los hongos comestibles, funcionales y medicinales a la construcción de un paradigma sobre la producción, la dieta, la salud y la cultura en el sistema agroalimentario de México. In Ciencia, Tecnología e Innovación en el Sistema Agroalimentario de México; Martínez-Carrera, D., Ramírez-Juárez, J., Eds.; Editorial del Colegio de Posgraduados: San Luis Huexotla, Texcoco, México, 2016; pp. 581-640.

6. Carrasco-González, J.A.; Serna-Saldívar, S.O.; Gutiérrez-Uribe, J.A. Nutritional composition and nutraceutical properties of the Pleurotus fruiting bodies: potential use as food ingredient. J. Food Compos. Anal. 2017, 58, 69-81.

7. Gomes-Corrêa, R.C.; Brugnari, T.; Bracht, A.; Peralta, R.M.; Ferreira, I.C.F.R. Biotechnological, nutritional and therapeutic uses of Pleurotus spp. (Oyster mushroom) related with its chemical composition: a review on the past decade findings. Trends Food Sci. Technol. 2016, 50, 103-117.

8. Llauradó-Maury, G.; Morris-Quevedo, H.J.; Heykers, A.; Lanckacker, E.; Cappoen, D.; Delputte, P.; Vanden Berghe, W.; Salgueiro, Z.; Cos, P. Differential induction pattern towards classically activated macrophages in response to an Immunomodulatory extract from Pleurotus ostreatus mycelium. J. Fungi 2021, 7, 206.

9. Morris, H.J.; Llauradó, G.; Beltrán, Y.; Lebeque, Y.; Batista, P.L.; Moukha, S.; Perraud-Gaime, I.; García, N.; Bermúdez, R.C.; Bidart, M.; Cos, P.; Hernández, E., Diez, J.C. Immunomodulating and antitumor properties of Pleurotus sp. in Cuba. In Updates on Tropical Mushrooms. Basic and Applied Research; Sánchez, J.E., Mata, G., Royse, D.J., Eds.; El Colegio de la Frontera Sur: San Cristóbal de Las Casas, Chiapas, México, 2018; pp. 159-180.

10. Sánchez, J.E.; Liedo, P. Propiedades antioxidantes de Pleurotus spp. In La biología, el cultivo y las propiedades nutricionales y medicinales de las setas Pleurotus spp.; Sánchez, J.E., Royse, D.J., Eds.; El Colegio de la Frontera Sur: San Cristóbal de las Casas, Chiapas, México, 2017; pp. 197-209.

11. Beltrán, Y.; Morris, H.J.; Oliva, D.; Batista, P.L.; Llauradó, G. Composición micoquímica y actividad antioxidante de la seta Pleurotus ostreatus en diferentes estados de crecimiento. Acta Biol. Colomb. 2021, 26, 89-98.

12. Aishah, M.S.; Wan Rosli, W.I. The effect of addition of oyster mushroom (Pleurotus sajor-caju) on nutrient composition and sensory acceptation of selected wheat- and rice-based products. Int. Food Res. J. 2013, 20, 183-188.

13. Bello, M.; Oluwamukomi, M. O.; Enujiugha, V. N. Nutrient composition and sensory properties of biscuit from mushroomwheat composite flours. Arch. Curr. Res. Int. 2017, 9, 1-11.

14. Jamangapé, R.; Palacios, G.; Caballero, A.; Zea, S.G.; Meza, P.I.; Álvarez, P. Evaluación proximal y sensorial de pasta Fettuccinie con sustitución parcial con harina de setas Pleurotus ostreatus. Espacio I+D, Innovación y Desarrollo 2019, VIII, 114-127.

15. Das, R.; Sarker, M.; Lata, M.B.; Islam, M.A.; Al Faik, M.A.; Sarkar, S. Physicochemical properties and sensory evaluation of sponge cake supplemented with hot air and freeze dried oyster mushroom (Pleurotus sajor-caju). World J. Eng. Technol. 2020, 8 , 665-674.

16. Angulo-Bejarano, P.I.; Martínez-Cruz, O.; Paredes-López, O. Phytochemical content, nutraceutical potential and biotechnological applications of an ancient Mexican plant: nopal (Opuntia ficus-indica). Curr. Nutr. Food Sci. 2014, 10, $196-217$.

17. El-Mostafa, K.; El Kharrassi, Y.; Badreddine, A.; Andreoletti, P. Nopal cactus (Opuntia ficus-indica) as a source of bioactive compounds for nutrition, health and disease. Molecules 2014, 19, 14879-14901.

18. Mouas, N.T.; Kabouche, Z.; Bellel, N.; Chertout, L.K. Opuntia ficus-indica a mediterranean diet product. Proceedings 2021, 68, x. https://doi.org/10.3390/xxxxx

19. Hernández-García, F.; Andreu-Coll, L.; Cano-Lamadrid, M.; López-Lluch, D.; Carbonell-Barrachina, A.A.; Legua-Murcia, P. Valorization of prickly pear [Opuntia ficus-indica (L.) Mill]: nutritional composition, functional properties and economic aspects. In Invasive species - introduction pathways, economic impact, and possible management options; El-Shafie, H., Eds.; IntechOpen: London, UK, 2020; pp. 1-16.

20. El-Hawary, S.S.; Sobeh, M.; Badr, W.K.; Abdelfattah, M.A.O.; Ali, Z.Y.; El-Tantawy, M.E.; Rabeh, M.A.; Wink, M. HPLC- PDAMS/ MS profiling of secondary metabolites from Opuntia ficus-indica cladode, peel and fruit pulp extracts and their antioxidant, neuroprotective effect in rats with aluminum chloride induced neurotoxicity. Saudi J. Biol. Sci. 2020, 27, $2829-2838$.

21. Perucini-Avendaño, M.; Nicolás-García, M.; Jiménez-Martínez, C.; Perea-Flores, M.J.; Gómez-Patiño, M.B.; Arrieta-Báez, D.; Dávila-Ortiz, G. Cladodes: chemical and structural properties, biological activity, and polyphenols profile. Food Sci. Nutr. 2021, 9, 4007-4017. 
22. Soriano-García, M.; Aguirre-Díaz, I.S. Nutritional functional value and therapeutic utilization of Amaranth. In Nutritional value of amaranth; Waisundara, V., Eds.; IntechOpen: London, UK, 2019; pp. 1-16.

23. Peter, K., Gandhi, P. Rediscovering the therapeutic potential of Amaranthus species: A review. Egypt. J. Basic Appl. Sci. 2017, 4, 196-205.

24. Sarker, U.; Hossain, M.M.; Oba, S. Nutritional and antioxidant components and antioxidant capacity in green morph Amaranthus leafy vegetable. Sci. Rep. 2020, 10, 1336.

25. Romo-Araiza, A.; Ríos-Hoyo, A.; Ibarra, A.; Hernández-Ortega, M.; Gutiérrez-Salmeán, G.; Meneses-Mayo, M. Effect of a formulation with nopal (Opuntia ficus indica), amaranth (Amaranthus cruentus) and mushroom (Pleurotus ostreatus) in a murine model of diet-induced cardiometabolic disruptions. Insights Nutr. Metabol. 2018, 2, 5-13.

26. Innova Market Insights. Top Ten Trends for 2020. Available online: https://foodindustryexecutive.com/2019/11/innova-announces-top-10-food-trends-for-2020/ (accessed on 11 September 2021).

27. Zlatanović, S.; Kalušević, A.; Micić, D.; Laličić-Petronijević, J.; Tomić, N.; Ostojić, S.; Gorjanović, S. Functionality and storability of cookies fortified at the industrial scale with up to 75\% of apple pomace flour produced by dehydration. Foods $2019,8,561$.

28. Uriarte-Frías, G. Evaluación del contenido de compuestos polifenólicos y actividad antioxidante de galletas elaboradas con amaranto, nopal y hongo Pleurotus ostreatus. Ms dissertation. Posgrado en Nutrición Clínica, Universidad Anáhuac México, Huixquilucan, Estado de México, 9 December 2016.

29. AOAC. Official methods of analysis, 18 ed.; Association of Official Analytical Chemists, AOAC International: Arlington, VA, USA, 2006.

30. Singleton, V.L.; Rossi, J.A. Colorimetry of total phenolics with phosphomolybdic-phosphotungstic acid reagents. Am. J. Enol. Vitic. 1965, 16, 144-158.

31. Ramírez-Sánchez, I.; Maya, L.; Ceballos, G.; Villareal, F. Fluorescent detection of (-)-epicatechin in microsamples from cacao seeds and cocoa products: comparison with Folin-Ciocalteu method. J. Food Compos. Anal. 2010, 23,790-793.

32. Zhishen, J.; Mengcheng, T.; Jianming, W. The determination of flavonoid contents in mulberry and their scavenging effects on superoxide radicals. Food Chem. 1999, 64, 555-559.

33. Re, R.; Pellegrini, N.; Proteggente, A.; Pannala, A.; Yang, M.; Rice-Evans, C. Antioxidant activity applying an improved ABTS radical cation decolorization assay. Free Radic. Biol. Med. 1999, 26, 1231-1237.

34. Sakhare, S.D.; Inamdar, A.A.; Soumya, C.; Indrani, D.; Venkateswara-Rao, G. Effect of flour particle size on microstructural, rheological and physico-sensory characteristics of bread and south Indian parotta. J. Food Sci. Technol. 2014, 51, 4108-4113.

35. Figueroa-Cares, I.; Martínez-Damián, M.T.; Rodríguez-Pérez, E.; Colinas-León, M.T.; Valle-Guadarrama, S.; Ramírez-Ramírez, S.; Gallegos-Vázquez, C. Pigments content, other compounds and antioxidant capacity in 12 cactus pear cultivars (Opuntia spp.) from México. Agrociencia 2010, 44, 763-771.

36. Mota, J.; Lima, A.; Ferreira, R.B.; Raymundo, A. Lupin seed protein extract can efficiently enrich the physical properties of cookies prepared with alternative flours. Foods 2020, 9, 1064.

37. Ferrante, A.A.; Martins, I.S.; Silva, L.A.; Percário, S.; Ferreira, M.E.S. Analytical methodology for determination of the plasma antioxidant capacity through the radical 2,2-azino-bis-3-ethylbenzthiazoline-6-sulfonic acid (ABTS). Aust. J. Basic Appl. Sci. 2019, 13, 19-22.

38. Subiria-Cueto, R.; Larqué-Saavedra, A.; Reyes-Vega, M.L.; de la Rosa, L.A.; Santana-Contreras, L.E.; Gaytán-Martínez, M.; Vázquez-Flores, A.A.; Rodrigo-García, J.; Corral-Avitia, A.Y.; Núñez-Gastélum, J.A.; Martínez-Ruiz, N.R. Brosimum alicastrum Sw. (Ramón): an alternative to improve the nutritional properties and functional potential of the wheat flour tortilla. Foods 2019, $8,613$.

39. Secretaria de Salud Norma Oficial Mexicana NOM-247-SSA1-2008, Productos y Servicios. Cereales y sus productos. Cereales, harinas de cereales, sémolas o semolinas. Alimentos a base de: cereales, semillas comestibles, de harinas, sémolas o semolinas o sus mezclas. Gobierno Federal: Ciudad de México, Mexico, 2008.

40. Szydlowska-Czerniak, A.; Poliński, S.; Momot, M. Optimization of ingredients for biscuits enriched with rapeseed press cakechanges in their antioxidant and sensory properties. Appl. Sci. 2021, 11, 1558.

41. Amarasinghe, N.K.; Wickramasinghe, I.; Wijesekara, I.; Thilakarathna, G.; Deyalage, S.T. Functional, physicochemical, and antioxidant properties of flour and cookies from two different banana varieties (Musa acuminata cv. Pisang awak and Musa acuminata cv. Red dacca). Int. J. Food Sci. 2021, Article ID 6681687.

42. de Oliveira Silva, F.; Miranda, T.G.; Justo, T.; da Silva Frasão, B.; Conte-Junior, C.A.; Monteiro, M.; Perrone, D. Soybean meal and fermented soybean meal as functional ingredients for the production of low-carb, high-protein, high-fiber and high isoflavones biscuits. LWT-Food Sci. Technol. 2018, 90, 224-231.

43. Starowicz, M.; Arpaci, S.; Topolska, J.; Wronkowska, M. Phytochemicals and antioxidant activity in oat-buckwheat dough and cookies with added spices or herbs. Molecules 2021, 26, 2267.

44. Mahloko, L.M.; Silungwe, H.; Mashau, M.E.; Kgatla T.E. Bioactive compounds, antioxidant activity and physical characteristics of wheat-prickly pear and banana biscuits. Heliyon 2019, 5, e02479.

45. Salehi, F. Characterization of different mushrooms powder and its application in bakery products: a review. Int. J. Food Prop. 2019, 22, 1375-1385. 
46. Msaddak, L.; Abdelhedi, O.; Kridene, A.; Rateb, M.; Belbahri, L.; Ammar, E.; Nasri, M.; Zouari, N. Opuntia ficus-indica cladodes as a functional ingredient: bioactive compounds profile and their effect on antioxidant quality of bread. Lipids Health Dis. 2017, 16, 32.

47. Anchondo-Trejo, C.; Loya-Carrasco, J.A.; Galicia-García, T.; Estrada-Moreno, I.; Mendoza-Duarte, M.; Castellanos-Gallo, L.; Márquez-Meléndez, R.; Portillo-Arroyo, B.; Soto-Figueroa, C. Development of a third generation snack of rice starch enriched with Nopal flour (Opuntia ficus indica). Molecules 2021, 26, 54.

48. Chauhan, A.; Saxena, D.C.; Singh, S. Total dietary fibre and antioxidant activity of gluten free cookies made from raw and germinated amaranth (Amaranthus spp.) flour. LWT- Food Sci. Technol. 2015, 63, 939-945.

49. Pastushkova, E.; Kryukova, E.; Arisov, A.; Tiunov, V.; Kokoreva, L. Use of non-traditional types of plant raw materials for food production within the framework of food security. E3S Web of Conferences 2020, 222, 06027.

50. Culetu, A.; Susman, I.E.; Duta, D.E.; Belc, N. Nutritional and functional properties of gluten-free flours. Appl. Sci. $2021,11,6283$.

51. Lelley, J.L. Aspectos nutritivos de las setas Pleurotus spp. In La biología, el cultivo y las propiedades nutricionales y medicinales de las setas Pleurotus spp.; Sánchez, J.E, Royse, D.J. Eds.; El Colegio de la Frontera Sur: San Cristóbal de las Casas, Chiapas, México, 2017; pp. 177-196.

52. Lebeque, Y.; Morris, H.J.; Beltrán, Y.; Llauradó, G.; Gaime-Perraud, I.; Meneses M.; Moukha, S.; Bermúdez, R.C.; García, N. Proximal composition, nutraceutical properties and acute toxicity study of Pleurotus ostreatus mushroom powder. Int. J. Med. Mushr. 2018, 20, 1185-1195.

53. D'Amico, S.; Schoenlechner, R. Amaranth: its unique nutritional and health-promoting attributes. In Gluten-Free Ancient Grains, 1st ed.; Taylor, J., Awika, J., Eds.; Elsevier-Woodhead Publishing: Cambridge, UK, 2017; pp. 131-159.

54. Soriano-García, M.; Arias-Olguín, I.I.; Carrillo-Montes, J.P.; Rosas-Ramírez, D.G.; Mendoza-Figueroa, J.S.; Flores-Valverde, E.; Valladares-Rodríguez, M.R. Nutritional functional value and therapeutic utilization of amaranth. J. Anal. Pharm. Res. 2018, 7, 596-600.

55. Kozarski, M.; Klaus, A.; Jakovljevic, D.; Todorovic, N.; Vunduk, J.; Petrovic, P.; Niksic, M.; M. Vrvic, M.; van Griensven, L. Antioxidants of edible mushrooms. Molecules 2015, 20, 19489-19525.

56. Munteanu, I.G.; Apetrei, C. Analytical methods used in determining antioxidant activity: a review. Int. J. Mol. Sci. 2021, 22, 3380.

57. Rocchetti, G.; Lucini, L.; Rodriguez, J.M.L.; Barba, F.J.; Giuberti, G. Gluten-free flours from cereals, pseudocereals and legumes: phenolic fingerprints and in vitro antioxidant properties. Food Chem. 2019, 271, 157-164.

58. Atri, N.S.; Sharma, S.K.; Joshi, R.; Gulati, A.; Gulati A. Nutritional and nutraceutical composition of five wild culinary-medicinal species of genus Pleurotus (Higher Basidiomycetes) from Northwest India. Int. J. Med. Mushr. 2013, 15, 49-56.

59. Beltrán, Y.; Morris, H.J.; Aguirre, R.I.; Quevedo, Y.; Armando, T.; Vázquez, R.; Llauradó, G., Bermúdez, R.C.; Lebeque, Y.; Moukha, S.; Gaime-Perraud, I.; Cos, P. In Abstract Book of the 15th International Conference on Oxidative Stress Reduction, Redox Homeostasis and Antioxidants, Paris, France. 22-24 June 2015; Edeas, M., Ricchetti, M., Eds.; International Society of Antioxidants in Nutrition and Health: Paris, France, 2015; p. 97.

60. Celis-Fabian E.F. Potencial nutracéutico de cladodios de nopal (Opuntia spp). Ms dissertation. Posgrado en Alimentos del Centro de la República, Universidad Autónoma de Querétaro, Querétaro, México, October 2009.

61. Lemos-Alves, F.A.; Pereira de Andrade, A.; Alcântara-Bruno, R.L.; Vasconcelos-Silva, M.G.; Vanderlei de Souza, M.F.; Cordeiro dos Santos, D. Seasonal variability of phenolic compounds and antioxidant activity in prickly pear cladodes of Opuntia and Nopalea genres. Food Sci. Technol., Campinas 2017, 37, 536-543.

62. Bensadón, S.; Hervert-Hernández, D.; Sáyago-Ayerdi, S.G.; Goñi, I. Byproducts of Opuntia ficus-indica as a source of antioxidant dietary fiber. Plant Foods Hum. Nutr. 2010, 65, 210-216.

63. Medina-Torres, L.; Vernon-Carter, E.J.; Gallegos-Infante, A.; Rocha-Guzman, N.E.; Herrera-Valencia, E.E.; Calderas, F.; JiménezAlvarado, R. Study of the antioxidant properties of extracts obtained from nopal cactus (Opuntia ficus-indica) cladodes after convective drying. J. Sci. Food Agric. 2011, 91, 1001-1005.

64. Msaddak, L.; Siala, R.; Fakhfakh, N.; Ayadi, M.A.; Nasri, M.; Zouari, N. Cladodes from prickly pear as a functional ingredient: Effect on fat retention, oxidative stability, nutritional and sensory properties of cookies. Int. J. Food Sci. Nutr. 2015, 66, 851-857.

65. Palermo, M.; Pellegrini, N.; Fogliano, V. The effect of cooking on the phytochemical content of vegetables. J. Sci. Food Agric. 2014, 94, 1057-1070.

66. López.Mejía, O.A.; López-Malo, A.; Palou, E. Antioxidant capacity of extracts from amaranth (Amaranthus hypochondriacus L.) seeds or leaves. Ind. Crop Prod. 2014, 53, 55-59.

67. Jo, H.J.; Chung, K.H.; Yoom, J.A.; Lee, K.J.; Song, B.C.; An, J.H. Radical scavenging activities of tannin extracted from amaranth (Amaranthus caudatus L.). J. Microbiol. Biotechnol. 2015, 25, 795-802.

68. Kumar, B.S.A.; Lakshman, K.; Jayaveera, K.N.; Sheshadri Shekar, D.; Narayan Swamy, V.B.; Saleemulla, K. In vitro $\alpha$-amylase inhibition and antioxidant activities of methanolic extract of Amaranthus caudatus Linn. Oman Med. J. 2011, $26,166-170$.

69. Vollmanova, A.; Margitanova, E.; Toth, T.; Timoracka, M.; Urminska, D.; Bojnanska, T.; Čicova, L.Cultivar influence on total polyphenol and rutin contents and total antioxidant capacity in buckwheat, amaranth and quinoa seeds. Czech J. Food Sci. 2013, 31, 589-595.

70. Chinma, C.E.; Gernah, D.I. Physicochemical and sensory properties of cookies produced from cassava/soybean/mango composite flours. J. Food Technol. 2007, 5, 256260. 
71. Ndangui, C.B.; Petit, J.; Gaiani C.; Nzikou, J.M.; Scher, J. Impact of thermal and chemical pretreatments on physicochemical, rheological and functional properties of sweet potato (Ipomea batatas Lam) flour. Food Bioproc. Technol. $2014,7,36183628$.

72. Lu, X.; Brennan, M.A.; Guan, W.; Zhang, J.; Yuan, L.; Brennan, C.S. Enhancing the nutritional properties of bread by incorporating mushroom bioactive compounds: the manipulation of the predictive glycaemic response and the phenolic properties. Foods 2021, 10, 731.

73. Sakač, M.B.; Gyura, J.F.; Mišan, A.C.; Šereš, Z.I.; Pajin, B.S.; Šoronja-Simovic, D.M. Antioxidant activity of cookies supplemented with sugar beet dietary fiber. Sugar Ind. 2011, 136, 151-157.

74. Farzana, T.; Mahajan, S. Effect of Incorporation of soy flour to wheat flour on nutritional and sensory quality of biscuits fortified with mushroom. Food Sci. Nutr. 2015, 3, 363-369.

75. Chen, C.; Han, Y.; Li, S.; Wang, R.; Tao, Ch. Nutritional, antioxidant, and quality characteristics of novel cookies enriched with mushroom (Cordyceps militaris) flour. CyTA - J. Food 2021, 19, 137-145.

76. Kolawole, F.L..; Akinwande, B.A.; Adeomowaye, B.I. Physicochemical properties of novel cookies produced from orangefleshed sweet potato cookies enriched with sclerotium of edible mushroom (Pleurotus tuber-regium). J. Saudi Soc. Agric. Sci. 2020, 19, 174-178.

77. Feitosa Teles, F.F.; Stull, J.W.; Brown, W.H.; Whiting, F.M. Amino and organic acids of the prickly pear cactus (Opuntia ficus indica L.). J. Sci. Food Agric. 1984, 35, 421-425.

78. Raman, J.; Jang, K.Y.; Oh, Y.L.; Oh, M.; Im, J.H.; Lakshmanan, H.; Sabaratnam, V. Cultivation and nutritional value of prominent Pleurotus spp.: an overview. Mycobiology 2021, 49, 1-14.

79. Morales de León, J.C.; Bourges-Rodríguez, H.; Camacho-Parra, M.E. Tablas de composición de alimentos y productos alimenticios, versión condensada 2015; Instituto Nacional de Ciencias Médicas y Nutrición Salvador Zubirán: Ciudad de México, México, 2016; p. 651.

80. Secretaría de Salud. Norma Oficial Mexicana NOM-086-SSA1-1994, Bienes y servicios. Alimentos y bebidas no alcohólicas con modificaciones en su composición. Especificaciones nutrimentales. Gobierno Federal: Ciudad de México, Mexico, 1995.

81. Elhassaneen, Y.; Ragab, R.; Mashal, R. Improvement of bioactive compounds content and antioxidant properties in crackers with the incorporation of prickly pear and potato peels powder. Int. J. Nutr. Food Sci. 2016, 5, 5561.

82. Miranda-Ramos, K.C.; Sanz-Ponce, N.; Haros, C.M. Evaluation of technological and nutritional quality of bread enriched with amaranth flour. LWT Food Sci. Technol. 2019, 114, 108418.

83. Nanditha, B.; Prabhasankar, P. Antioxidants in bakery products: a review. Crit. Rev. Food Sci. Nutr. 2009, 49, 1-27. 